\section{"Nikt nie widział w tym niczego szczególnego". 0 kilku przeoczeniach i uniwersalizacjach w Dwóch ojczyznach Jana Józefa Lipskiego i o tym, co z nich wynika}

Agnieszka Graff

TEKSTY DRUGIE 2021, NR 3, S. 17-32

DOI: 10.18318/td.2021.3.2 | ORCID: 0000-0003-0468-0376

$\mathbf{E}$ sej Lipskiego nie jest tekstem analitycznym, choć jący pewien projekt polityczny i światopoglądowy. Jesteśmy jego spadkobiercami, a może raczej spadkobiercami jego klęski. My, czyli szeroko rozumiana posttransformacyjna liberalna i lewicowa inteligencja. Siła tego tekstu jest niezaprzeczalna. Zaproponowane w nim rozróżnienie patriotyzmu krytycznego i narodowego szowinizmu stanowiło, a dla wielu osób nadal stanowi, moralną i polityczną busolę. Jednocześnie, jak postaram się pokazać, zaproponowany przez Lipskiego sposób myślenia przyczynił się do powstania hegemonii Kościoła katolickiego w demokratycznej Polsce oraz do wykluczenia z publicznej debaty kwestii kobiecej.

Nie zamierzam z Lipskim polemizować - po czterdziestu latach byłoby to absurdalne. Chcę jednak przemyśleć na nowo konstrukcję tego tekstu, a zarazem formacji ideowej, dla której jest to tekst kluczowy. Czynię to z miejsca, w którym się znaleźliśmy: kraju, w którym rządzą prawicowi populiści i nacjonaliści w ścisłym
Agnieszka Graff dr hab., profesorka w Ośrodku Studiów Amerykańskich UW. Autorka książek o płci w polskim dyskursie publicznym: Świat bez kobiet (2001; wydanie poszerzone 2021), Rykoszetem (2008), Magma (2011) i Matka feministka (2014). Publikowała m.in. w "Public Culture”, "Feminist Studies", "Signs" i „Czasie Kultury."Wkrótce ukaże się książka Anti-gender Politics in the Populist Moment (Routledge, współautorka: Elżbieta Korolczuk) o międzynarodowej mobilizacji przeciw „ideologii gender" i jej związkach z falą prawicowego populizmu. 
sojuszu z Kościołem katolickim. Nie twierdzę, rzecz jasna, że jest to wina Lipskiego - przeciwnie, obecna sytuacja jest z perspektywy jego idei katastrofą. Szkic Lipskiego czytam jako manifest ideowy środowiska, którego ówczesne i późniejsze decyzje - a także zaniechania i przeoczenia - wywarły ogromny wpływ na dalszy bieg historii.

Zacznę jednak od osobistej deklaracji: esej Lipskiego był dla mnie lekturą formacyjną. Przeczytane u progu dorosłości Dwie ojczyzny w znacznym stopniu ukształtowały moją tożsamość, mój sposób myślenia, mój stosunek do Polski, motywacje późniejszych zaangażowań, a także zwrotów i rozczarowań. Cała jestem z Dwóch ojczyzn, a raczej niemal cała. Owo „niemal” czyni niemałą, zmieniającą się w czasie różnicę, której zamierzam się przyjrzeć. Jednak punktem wyjścia do krytycznego namysłu będzie w moim przypadku opowieść o trudnej miłości do tego tekstu i zawartego w nim projektu krytycznego patriotyzmu. Projekt ten, przez lata nadający sens mojej aktywności, poniósł klęskę. Osobista przygoda z tekstem Lipskiego jest, jak sądzę, jakoś reprezentatywna dla części mojego pokolenia - dlatego zacznę od wspomnień.

\section{Kółko, czyli dylemat}

Wiosna 1986, a może 1987 roku, druga lub trzecia klasa liceum, schyłkowa komuna. Grupa nastolatków siedzi w kręgu na dywanie i zażarcie dyskutuje. Obradom przewodniczy dwóch studentów, jeden psychologii, drugi filozofii. Obaj są zaangażowani w opozycję (bardzo nam to imponuje); obaj mają żydowskie korzenie (o tym nie wiemy, a może wiemy, ale wypieramy tę wiedzę jako nieistotną) ${ }^{1}$. Spotkanie kółka samokształceniowego poświęcone Dwóm ojczyznom odbywa się u mnie w domu, więc jestem nim szczególnie przejęta. Towarzyszy temu młodzieńcza egzaltacja, niejasne poczucie, że uczestniczymy w czymś ważnym i antysystemowym. Pierwsza teza Lipskiego jest dla nas oczywista: tak, istnieje coś takiego jak tożsamość narodowa, głębokie przywiązanie do ojczyzny, być może nawet istnieje coś takiego jak „, charakter narodowy" Polaków. Utożsamiamy się z projektowanym przez ten tekst odbiorcą: „nawet jeśli uważa ktoś z nas, że największym poetą, jakiego ludzkość

1 Jednym ze studentów prowadzących kółko samokształceniowe był Krzysztof Srebrny, obecnie wybitny psychoanalityk i psychoterapeuta. W kwietniu 2021 roku napisał na swoim profilu na Facebooku gorzki post, który przytaczam za jego zgodą: „Właśnie dokonując samospisu, dokonałem apostazji z polskości. Coraz bardziej zgadzam się z Jarosławem Kaczyńskim i Jackiem Kurskim, że polskość zawiera się w paśmie od (symbolicznie) Konfederacji Barskiej do (symbolicznie) Brygady Świętokrzyskiej. Czyli beze mnie". 
wydała, jest Goethe, Dante lub Shakespeare - to jednak Mickiewicz i Słowacki jakoś inaczej tkwią w nas (czy my w nich), bo wrosły nam chyba już na zawsze w narodową pamięć lata niewoli i walki o wolnośćn". Tak, to o nas. Czujemy, że język, poezja i pamięć zniewolenia są sednem sprawy. Teza druga: istnieją dwie formy patriotyzmu - ten otwarty, krytyczny, zanurzony w chrześcijańskim umiłowaniu bliźniego i ten zamknięty, szowinistyczny, megalomański, wrogi wobec sąsiadów, nieufny wobec wszelkiej krytyki „swoich”. Zachwyca nas jasność i prostota tego podziału, zwłaszcza zdanie „patriotyzm jest z miłości - i do miłości ma prowadzić, jakakolwiek inna jego forma jest deformacją etyczną"3. Znamy życiorys Lipskiego i traktujemy jego słowa jako drogowskaz na dalszą polityczną drogę. „Pojęcia etyczne naszego kręgu kulturowego zostały ukształtowane głównie przez chrześcijaństwo" - to zdanie przyjmujemy jako prawdę oczywistą.

Pojawiają się wątpliwości. Część z nas podejrzewa, że nasza niezaprzeczalna „więź" ze Słowackim to efekt szkolnej edukacji polonistycznej, obsesyjnie skupionej na romantyzmie, a ignorującej literaturę światową. Ktoś sugeruje, że słowo „naród” - Lipski posługuje się nim nieustannie - należałoby zastąpić słowem „społeczeństwo". Ktoś się zastanawia, czy centralne rozróżnienie tekstu jest do utrzymania - wszak każdy swoją wersję nacjonalizmu nazywa patriotyzmem, cudzą chętnie piętnując jako nacjonalizm ${ }^{4}$. Czy będąc Polakami, czujemy się także obywatelami świata? Co by to miało znaczyć wobec faktu, że niemal nikt z nas nie był za granicą? Rozmowa schodzi na opisane przez Lipskiego winy Polaków wobec Niemców i spór wokół listu biskupów z 1965 roku - nie do końca za nim nadążamy. O stosunkach polsko-ukraińskich, rzezi wołyńskiej i UPA w PRL-owskiej szkole się nie mówiło, nasze spotkanie zamienia się więc w lekcję historii, by po chwili przeistoczyć się w infantylny, czysto abstrakcyjny spór dotyczący tożsamości i norm moralnych. Ktoś proponuje dylemat: stoisz na skrzyżowaniu, czekając na zielone światło. Obok ciebie dwie staruszki - Polka i Niemka - które ewidentnie potrzebują pomocy. Którą z nich przeprowadzisz przez jezdnię?

2 J.J. Lipski Dwie ojczyzny, dwa patriotyzmy (uwagi o megalomanii narodowej i ksenofobii Polaków), w: tegoż Pisma polityczne. Wybór, oprac. Ł. Grabal, Wydawnictwo Krytyki Politycznej, Warszawa 2011, s. 145 .

3 Tamże, s. 146.

4 Wiele lat później spotkałam tę samą argumentację w książce Michaela Billiga Banal Nationalism, Sage London 2009. Nie przekonała mnie jednak. Do dziś uważam to rozróżnienie za cenne i politycznie użyteczne. 
Nie pamiętam, po której stronie sporu się opowiedziałam. Dziś przykuwają moją uwagę dwa szczegóły, dwa przemilczenia, które znajduję w naszej dyskusji, a także w odczytanym na nowo eseju Lipskiego. Pierwsze to płeć. Rozmawialiśmy o hipotetycznych staruszkach płci żeńskiej. One bezradnie czekały na naszą pomoc, my mieliśmy wejść w rolę mniej lub bardziej patriotycznych, ale najzupełniej uniwersalnych podmiotów obdarzonych mocą sprawczą. Tymczasem na dywanie siedziały w większości dziewczyny, naszymi przewodnikami po świecie myśli byli dwaj młodzi mężczyźni, a zadaną lekturą - tekst napisany przez męskiego autora (wcześniej czytaliśmy młodego Marksa, Aaronsona i Ossowskich). Ten podział ról był nieistotny, wręcz niewidzialny. Niewidzialny był też zabieg uniwersalizacji, czyli unieważnienie płci w dyskusji o tożsamości narodowej.Żadnej z nas, siedzących na dywanie młodych kobiet, nie przyszłoby do głowy, by się nad tym zastanowić. Drugie pominięcie dotyczy katolicyzmu. Przyjęliśmy tezę Lipskiego o chrześcijańskim podłożu otwartego patriotyzmu jako oczywistość, nie zastanawiając się specjalnie nad tym jak owo uniwersalistycznie pojęte chrześcijaństwo ma się do polskiego katolicyzmu. A był to katolicyzm daleki od uniwersalizmu: bogoojczyźniany, maryjny, martyrologiczny. Jego symbolem stanowiącym wówczas narodowe sanktuarium - kościół św. Stanisława Kostki na Żoliborzu. Groza śmierci księdza Popiełuszki i pamięć o nim - to było sedno naszego katolicyzmu i naszego patriotyzmu zarazem. Uczestniczyliśmy w kulcie Jana Pawła II, „polskiego papieża”, bywaliśmy na mszach za ojczyznę, znaliśmy na pamięć Barkę i Boże coś Polskę. Tłem dla patriotycznych uniesień były też antyaborcyjne wystawy, zdjęcia poszarpanych płodów ustawiane w niezliczonych kościołach. A jednak nie przyszło nam do głowy zastanowić się, jak owo uwikłanie religii w patriotyzm (a może jednak nacjonalizm?) ma się do chrześcijańskiego uniwersalizmu, który tak nas w tekście Lipskiego zachwycał.

Dziś uważam, że te dwa pominięcia są istotnym elementem projektu politycznego, którego manifestem jest esej Lipskiego. Opozycja demokratyczna w sojuszu z Kościołem miała obalić w Polsce komunizm, a następnie zbudować w naszym kraju demokrację. Sojusz ten, oparty był na pewnej mitologizacji oraz na licznych przemilczeniach, z których kluczowe dotyczyło rzeczywistego wsparcia episkopatu dla Solidarności ${ }^{5}$. Opozycyjna młodzież, do której

5 Jedno z tych strategicznych przemilczeń dotyczyło homilii Stefana Wyszyńskiego wygłoszonej na Jasnej Górze 26 sierpnia 1980 r. Wzywał on wówczas do zaprzestania strajków: „Musimy mieć roztropność kierowniczą, po łacinie nazywa się to prudentia gubernativa, czyli roztropność zarządzania. Wiemy, że w wielkim trudzie odbudowania Polski zrobiono już bardzo wiele, ale jeszcze dużo zostało do zrobienia. Trzeba ciągle zwielokrotniać wysiłek pracy, pogłębiać 
należałam, czyli późniejsze pokolenie transformacji, miała sobie ten projekt przyswoić razem z opowieścią o wielkim długu opozycji demokratycznej wobec Kościoła. Nie należało stawiać niewygodnych pytań, w końcu chodziło o Polskę. Dziś nie możemy ich nie stawiać, bo nadal chodzi o Polskę. Musimy jednak mieć w pamięci również czas, w którym Lipski ten tekst napisał.

\section{Grunwald i prawdziwki, czyli kontekst}

Dwie ojczyzny powstały najprawdopodobniej na początku 1981 roku, podczas karnawału pierwszej Solidarności. Krytykowany przez Lipskiego narodowy szowinizm sączył się wówczas z dwóch źródeł. Pierwszym był narodowo-katolicki nurt opozycji, który próbował zarezerwować dla siebie określenie „opozycja niepodległościowa”. Polemistą Lipskiego był tu przede wszystkim Antonii Macierewicz, współzałożyciel i członek KOR, który przeciwstawiał nurt „lewicy laickiej” nurtowi „niepodległościowo-demokratycznemu”.,Operację słowną, stawiającą moich przyjaciół i mnie w opozycji do idei niepodległościowo-demokratycznej, traktuję jako chwyt niezbyt przyzwoity" - pisał Lipski ${ }^{6}$. Drugim źródłem dyskursu nacjonalistycznego było powstałe kilka miesięcy wcześniej reżimowe stowarzyszenie Grunwald, łączące idee komunistyczne z nacjonalizmem. W 1981 roku, w rocznicę marca 1968, pod pozorem hołdu składanego ofiarom stalinizmu próbowano wzniecić niechęć do opozycji za pomocą antysemickich kalek o żydokomunie. Przemawiający określali opozycjonistów mianem „farbowanych lisów”, sugerując, że KOR to Żydzi, którzy chcą wprowadzić w Polsce stalinizm.

Wiele wskazuje na to, że impuls do powstania eseju dała marcowa akcja Grunwaldu', ale równie istotny mógł być spór z Macierewiczem - i szerzej, z narodowo-katolickim nurtem Solidarności, czyli z działaczami, których Kuroń w swojej autobiografii określa mianem „prawdziwych Polaków” lub

jej poziom moralny, poczucie odpowiedzialności zawodowej, ażeby nastąpił należyty ład i porządek". Przekaz Prymasa Tysiąclecia został dyplomatycznie zignorowany przez organizatorów strajku w Stoczni, którzy tymczasem zabiegali o zorganizowanie dla strajkujących mszy. O napiętych relacjach opozycja-Kościół i późniejszej mitologizacji poparcia Kościoła dla opozycji ciekawie opowiada Bohdan Borusewicz w rozmowie z Rigamonti w Tok FM (27.04.2021, „Rzeczpospolita kościelna", odc. 1).

6 S. Kowalski Krytyka solidarnościowego rozumu. Studium z socjologii myślenia potocznego, Wydawnictwo PEN, Warszawa 1990, s. 155, przyp. 17.

7 Tak sądzi Łukasz Garbal, autor przypisów do wydanych przez Krytykę Polityczną Pism politycznych Lipskiego, s. 174, przyp. 1. 
„prawdziwków”. Stanowisko Lipskiego wyłożone w Dwóch ojczyznach - otwarty patriotyzm jako tożsamość polityczna etycznie przewyższająca nacjonalizm - stanowi zatem odpowiedź na uporczywe wykluczanie opozycyjnej lewicy z „nurtu niepodległościowego”. Nie był to spór abstrakcyjny. Kilka miesięcy później toczyła się już otwarta walka o miejsce członków KOR- u w Solidarności, a także o pamięć o KOR-ze wśród członków związku. W czerwcu 1981 roku Lipskiego wybrano do zarządu Regionu Mazowsze; we wrześniu był delegatem na I Krajowy Zjazd Związku w Gdańsku Oliwie. Doszło tam do żenującego sporu wokół wniosku o uchwalenie podziękowań związku dla KOR-u, którego rozwiązanie właśnie ogłoszono. Pojawił się bowiem kontrprojekt, w którym, jak pisze Kuroń, „nie było słowa o KOR, za to dużo o Polsce, która jest krajem katolickim, o chrześcijańskich tradycjach, i jedno zdanie pozytywne o opozycji demokratycznej"8. Konflikt stał się publiczny, na sali powstała wrzawa. Roztrzęsiony i zraniony tą sytuacją Lipski poprosił o głos, po czym stojąc przy mikrofonie, dostał ataku serca, stracił przytomność i został wyniesiony z sali.

Ten dramatyczny kontekst wyjaśnia, jak sądzę, specyficzne rozłożenie akcentów w tekście i szereg niedomówień dotyczących styku religii i tożsamości narodowej.Z jednej strony Lipski kładzie nacisk na chrześcijańskie korzenie postawy etycznej, z której wywodzi patriotyzm, z drugiej bardzo skrótowo traktuje polityczną rolę Kościoła katolickiego. Konstrukcja ta umożliwia sojusz lewicy laickiej z Kościołem - ten sam, któremu kilka lat wcześniej Adam Michnik poświęcił głośną książkę Kościót, lewica, dialog. Ów sojusz ma obronić lewicowy nurt opozycji przed „niezbyt przyzwoitymi chwytami” Macierewicza i innych "prawdziwków”, a z drugiej strony - przed antysemicką nagonką na KOR rozkręcaną przez Grunwald.

\section{Kościół, czyli autorytet}

Przejdźmy do konkretów, czyli przemilczeń i pominięć. Już pierwsza wzmianka ustawia Kościół w roli depozytariusza polskości i autorytetu moralnego. Lipski przywołuje słynny list biskupów z 1965 roku, tak opisując jego historyczne znaczenie:

Musiał jednak przyjść moment - jeśli chcieliśmy pozostać w kręgu chrześcijańskiej etyki i cywilizacji zachodnioeuropejskiej - by powiedzieć:

8 J. Kuroń Autobiografia, Krytyka Polityczna, Warszawa 2009, s. 627. 
„Wybaczamy i prosimy o wybaczenie”. W sytuacji zniewolenia narodu powiedział to największy niezależny autorytet moralny, jaki nam pozostał: Kościół polski. [...] Wyciągnięcie ręki przez Episkopat Polski do Episkopatu Niemiec było najśmielszym i najbardziej dalekowzrocznym czynem w powojennej historii Polski. ${ }^{9}$

Kościół hierarchiczny okazuje się zatem ostoją patriotyzmu otwartego, strażnikiem europejskiej tożsamości Polski, wrogiem nacjonalizmu. Zastanawiające, że Lipski nie wspomina ani słowem o prymasie Stefanie Wyszyńskim. Pomija też szerszy kontekst tego gestu - rozpoczęte wkrótce potem obchody tysiąclecia chrztu Polski w 1966 roku. Zdarzenia te nie były wyrazem uniwersalistycznych idei, przeciwnie - chodziło o trwałe utożsamienia narodu z katolicyzmem. Polak katolik - owa jedność, i tylko ona, miała przeciwstawić się autorytarnemu systemowi. Jak pisze Stanisław Obirek, Wyszyński odegrał kluczową rolę w procesie odreligijnienia i upolitycznienia polskiego katolicyzmu po drugiej wojnie światowej - w budowaniu w społeczeństwie przekonania, że „tylko Kościół katolicki ma moralne prawo reprezentowania polskości w przestrzeni publicznej"10. Lipski nie mógł o tym nie wiedzieć, ale też nie mógł o tym napisać.

A oto drugi fragment eseju Lipskiego, w którym pojawia się Kościół. Dotyczy tematu drażliwego, bo przyzwolenia tej instytucji na antysemickie wybryki w latach 30. XX wieku:

Władza, po śmierci Piłsudskiego coraz bardziej skłaniająca się ku faszyzującej prawicy, nie próbowała zbyt energicznie przeszkadzać awanturom, wyprawianym częściowo przez grupy znajdujące się w opozycji wobec sanacji, częściowo jednak przez jej sojuszników (ONR „Falanga”). Kościół przyglądał się temu obojętnie (z wyjątkiem tak drastycznych wypadków, jak pobicie w kościele księdza Pudra, neofity), a nawet część prasy katolickiej (np. „Mały Dziennik”) popierała antysemityzm."

I tyle, ani słowa więcej o antysemityzmie Kościoła przed wojną. Co ważniejsze, ani słowa o katolickim antysemityzmie Anno Domini 1981. Pod koniec

9 J.J. Lipski Dwie ojczyzny..., s. 150-151.

10 S. Obirek Polak katolik?, Wydawnictwo CiS, Stare Groszki 2015, S. 256.

11 J.J. Lipski Dwie ojczyzny..., s.164. 
tekstu temat katolicyzmu wraca w kontekście rozważań na temat „splotu wątków narodowych z religijnymi" i figury Polaka katolika. Lipski starannie oddziela tezę o ogromnym wpływie katolicyzmu na kulturę polską (teza ta, jego zdaniem jest rozsądna, choć dyskusyjna) od tezy utożsamiającej polskość z katolicyzmem (absurdalnej, bo wykluczającej z polskiej tradycji cały szereg wybitnych postaci - arian, protestantów, a także ateistów i agnostyków). Wywód ten, klarowny i przekonujący, zawiera jednak pewne istotne pominięcie, a może raczej niedomówienie. Otóż nie pada w nim słowo „Kościół”. Nie pojawia się żaden opis nacjonalistycznego nurtu polskiego katolicyzmu. Tekst Lipskiego napisany jest tak, jakby stanowiąca przedmiot namysłu zbitka Polak katolik była forsowana w Polsce przez pojedyncze osoby. Autor polemizuje z księdzem Sroką, publikującym w Gdańskim „Bratniaku” współtwórcą środowiska Ruchu Młodej Polski - ich spór okazuje się zresztą nieporozumieniem. Trudno się oprzeć wrażeniu, że Lipski próbuje w tym miejscu obejść potężną rafę, z której istnienia musiał sobie zdawać sprawę - mowa wszak o autorze studium Katolickie Państwo Narodu Polskiego.

I jeszcze jedno zaskakujące przeoczenie: w Dwóch ojczyznach nie ma wzmianki o Karolu Wojtyle. Dziś wiele osób czyta ten tekst, nie mając w pamięci zbiorowych uniesień, jakie towarzyszyły pierwszej pielgrzymce Jana Pawła II do kraju. Tak się składa, że ja pamiętam je doskonale - te rozmodlone i rozśpiewane tłumy na ulicach i placach, tysiące wizerunków papieża w oknach mieszkań. To był czas, gdy kult papieża Polaka był tożsamy z oporem wobec władzy. Lipski miał do tych zbiorowych przeżyć stosunek ambiwalentny, o czym pisał obszernie w eseju O wizycie Papieża (1979):

Euforia zachwytu, poczucie jedności, pełnej akceptacji bywają społecznie i moralnie potrzebne [...] Jest to jednak zarazem bardzo niebezpieczne. Polska megalomania - groteskowa reakcja na narodowe nieszczęścia i poniżenia - ma teraz dopiero żer, jakiego potrzebowała. „My, Polacy złote ptacy". Dotychczas wyżywać się to musiało na Koperniku i Monte Cassino. Jest obawa, że od takiego papieża, jak on się zapowiada [...] dostaniemy zupełnego zawrotu głowy i amoku kosmicznej megalomanii, to zaś nikomu jeszcze nie wyszło na zdrowie. ${ }^{12}$

Charakterystyczna fraza „my, Polacy złote ptacy” pojawia się w Dwóch ojczyznach w kontekście krytyki figury Polaka katolika, jednak wątek papieski

12 J.J. Lipski O wizycie Papieża - obserwacje, przeżycia, refleksje, w: tegoż Pisma polityczne, s. 76. 
zostaje tu pominięty. W cytowanym wyżej tekście o wizycie papieża Lipski otwarcie stawia pytanie, czy kult Jana Pawła II, skłonność do przyjmowania jego słów jako „nietykalnych", nie okaże się pożywką dla tendencji autorytarnych. W pisanych półtora roku później Dwóch ojczyznach to pytanie już się nie pojawia. Co się wydarzyło w tym czasie? Oczywiście Solidarność.

\section{Naród i płeć, czyli kim właściwie jest „osoba”}

Kategoria narodu jako pewnej wspólnoty wyobrażonej, by przywołać słynną koncepcję Bendicta Andersona ${ }^{13}$, nieuchronnie implikuje idee, obrazy i wymagania dotyczące męskości, kobiecości, a także porządku płci jako wymiaru porządku społecznego. Nie potrzebujemy genderowej teorii nacjonalizmu, ${ }^{14}$ by dostrzec płciowe uwikłanie idei narodu. Wskazuje na nie etymologia: natio (łac.) oznacza wszak narodziny, źródło. „Ojczyzna” zawiera w sobie słowo „ojciec”, podobnie zresztą jak „patriotyzm”. Kategoria narodu, o czym piszą liczni badacze tego pojęcia, kształtowała się w dużej mierze w analogii do rodziny. Czy można zatem myśleć o narodzie i nacjonalizmie, abstrahując od rozrodczości, od prawa kobiet do samostanowienia? Owszem, można. Tak właśnie myśli o narodzie Lipski. Trudno mu się dziwić - płeć nie była dla jego pokolenia humanistów kategorią kulturową, społeczną, a tym bardziej polityczną. Ani Lipskiemu, ani żadnej i żadnemu z nas - uczestników spotkania o Dwóch ojczyznach - nie przyszło do głowy, że temat naszej rozmowy można rozpatrywać pod tym kątem. O ile zatem w przypadku pominięć dotyczących Kościoła nie ma wątpliwości, że chodzi o pewną świadomą, motywowaną politycznie strategię pisarską, o tyle brak odniesień do kobiet i kwestii kobiecej w eseju Lipskiego jestem skłonna uznać za znak czasu. Zamierzam jednak ów brak obejrzeć bliżej, pytając o jego źródła, przejawy i konsekwencje.

Konstrukcja podmiotu etycznego i politycznego, o którym pisze Lipski i o którym zawzięcie debatowaliśmy w 1986 roku, decydując o losach hipotetycznych staruszek na pasach, jest całkowicie zuniwersalizowana. Jak już wspomniałam, decyzję w sprawie staruszek podejmuje „człowiek”

B. Anderson Wspólnoty wyobrażone. Rozważania o źródłach i rozprzestrzenianiu się nacjonalizmu, przeł. S. Amsterdamski, Znak, Kraków, 1997.

14 Warto zauważyć, że dwie kluczowe prace dotyczące tego splotu powstały później niż esej Lipskiego. Są to N. Yuval-Davis Gender and Nation, Sage, London 1997, i G. Mosse Nationalism and Sexuality. Middle-Class Morality and Sexual Norms in Modern Europe, University of Wisconsin Press, Madison 1985. 
najzupełniej neutralny pod względem płci, a przy tym uwznioślony jako „osoba" dokonująca ważnego wyboru. Osoba ludzka jest w tym ujęciu z definicji wolna, twórcza, samoświadoma, odpowiedzialna i zaangażowana. Działa na rzecz dobra wspólnego. Lipski był socjalistą, dla niego owo dobro oznaczało egalitarny porządek społeczny. My jednak, jak sądzę, używając słowa „osoba", nieświadomie posługiwaliśmy się językiem personalizmu katolickiego. To był nasz język domyślny, w którym kwestie społeczne chętnie wywodzono ze społecznej nauki papieża, ocenianej przez Lipskiego, nawiasem mówiąc, bardzo wysoko. ${ }^{15} \mathrm{Z}$ całą pewnością jednak owo dobro wspólne nie uwzględniało emancypacji kobiet. Osoba była domyślnie męska.

Wypada przyznać, że przemilczenie kwestii płci otwierało pewne możliwości. Stanowiło ono niewypowiedzianą podstawę naszego - młodych dziewcząt, kobiet - udziału w opozycyjnej debacie. Nie dostrzegałyśmy tego pominięcia i jego politycznych konsekwencji, bo tak ukształtowana podmiotowość dawała nam poczucie sprawczości. Symbolem tego mechanizmu - czytelnym, jak sądzę, do dziś - jest grana przez Krystynę Jandę postać Agnieszki w Człowieku z marmuru Andrzeja Wajdy (1976). Z gładko zaczesanymi włosami, ubrana w spodnie dzwony i męską koszulę, z niezmąconą pewnością siebie przemierza korytarz telewizji, awanturując się o prawo do zrobienia politycznego filmu. Ta kultowa scena odzwierciedla nie tylko fantazję Wajdy, ale także fantazję ówczesnych młodych kobiet o samych sobie. Inaczej niż ich rówieśnice na Zachodzie, które uczestniczyły wtedy w masowym ruchu feministycznym, Polki emancypowały się w opozycji do autorytarnego systemu. Sądzę, że masowo dostrzegły polityczny wymiar płci w państwie, w którym hegemonem politycznym jest niezmiennie Kościół, dopiero w 2016 roku, podczas tzw. czarnych protestów. Protesty z 2020 roku - te dotyczące praw osób LGBT+ i te, które nastąpiły w reakcji na wyrok Trybunału Julii Przyłębskiej w sprawie aborcji - przypieczętowały nową świadomość. Jednak w późnych latach 70. i całej kolejnej dekadzie nie istniał w zbiorowej wyobraźni pozytywny wizerunek feministki. Celem silnej kobiety było stać się pełnoprawną „osobą”, obdarzoną wewnętrzną wolnością i siłą, zbuntowaną wobec opresyjnego systemu. Ta właśnie emocja prowadzi Agnieszkę przez korytarz telewizji. Ta emocja towarzyszyła naszej rozmowie o Lipskim dekadę później.

Lipski nie był seksistą ani mizoginem. Był wybitnym opozycjonistą i nie mniej wybitnym intelektualistą, dla którego świat idei pozostawał

15 Zob. J.J. Lipski Po lekturze Encykliki „Redemptor hominis”, w: tegoż Pisma polityczne, s. 65-70. 
w oczywisty sposób światem męskim, prawa kobiet zaś nie miały znaczenia - na tle wielkiej historii kwestia ta była po prostu niewidzialna. Pokazuje to dobrze język, który pozostaje genderowo neutralny. W Dwóch ojczyznach nie pada ani słowo „kobieta”, ani słowo „mężczyzna”. Autor posługuje się słowem „osoba” (dwukrotnie), ale chętniej używa słowa „człowiek" (sześciokrotnie). Mamy zatem do czynienia nie tyle z pominięciem kobiet, ile z wymazaniem samej płci poprzez uniwersalizację kategorii osoby ludzkiej. A jednak wymienione w tekście osoby mają płeć - niemal zawsze męską. W horyzoncie intelektualnym Lipskiego, niesłychanie przecież bogatym, kobiet nie ma niemal wcale. Nie ma ich ani wśród wymienionych pisarzy, ani wśród bohaterów narodowych, ani wśród twórców patriotyzmu otwartego, ani wśród adwersarzy. Jedyne wspomniane z imienia i nazwiska kobiety to Maria Ossowska i Maria Dąbrowska ${ }^{16}$.

Te wyliczenia mogą się wydać małostkowe, nie mają one jednak charakteru pretensji czy demaskacji - to raczej pewna obserwacja. Brak kobiet w eseju Lipskiego nie jest niczym wyjątkowym; tak właśnie się wtedy myślało, tak się pisało, także w środowisku opozycyjnej lewicy i także wówczas, gdy pisały kobiety. W imaginarium tego czasu pojawiają się niekiedy wybitne jednostki płci żeńskiej, których twórczość dotyczy uniwersalnie pojętej kondycji ludzkiej: stąd w panteonie znamienitych postaci obecność Ossowskiej i Dąbrowskiej. Jednak kobiety ja k o ko bi et y, kwestia kobieca jako temat polityczny pozostają dla Lipskiego i jego ówczesnych odbiorców i odbiorczyń niewidzialne. Stąd, jak sądzę, brak nazwiska Zofii Nałkowskiej przy jednoczesnym przywołaniu jej ojca, Wacława Nałkowskiego. Wśród ważnych postaci, które zostałyby wykluczone z polskości, gdyby traktować ją jako równoznaczną z katolicyzmem, nie pojawia się też wzmianka o Irenie Krzywickiej i Tadeuszu Boyu Żeleńskim, postaciach kluczowych dla międzywojennych sporów o polskość i katolicyzm, a także, rzecz jasna, dla kwestii praw kobiet.

Kobiety nie stanowią w oczach autora odrębnej zbiorowości, mającej jakieś warte odnotowania interesy, doświadczenia czy własną historię. Płeć nijak nie odnosi się do tematu, któremu tekst jest poświęcony

16 Zdanie to brzmi następująco: „Trudno wyobrazić sobie kulturę polską ostatniego stulecia bez Edwarda Abramowskiego i małżeństwa Dawidów, bez Wacława Nałkowskiego i Ignacego Redlińskiego, bez Stefana Żeromskiego i Andrzeja Struga, bez Stefana Czarnowskiego i Tadeusza Kotarbińskiego, bez Edwarda Lipińskiego oraz Marii i Stanisława Ossowskich, bez Antoniego Słonimskiego i Marii Dąbrowskiej, bez Leszka Kołakowskiego"; ।.J. Lipski Dwie ojczyzny..., S. 171. 
- narodu. Jest częścią prywatności. Dyskutowano o zbiorowej tożsamości, nie poddając refleksji faktu, że ta zbiorowość w połowie składa się z kobiet. Same kobiety zaś nie kwestionowały ani tych założeń, ani towarzyszących im społecznych rytuałów. Przezroczystość i nieważność płci w debacie publicznej to cecha szczególna nie tylko opozycji lat 8o., ale też polskiej transformacji - jej spóźnionym efektem są masowe protesty Strajku Kobiet. Małgorzata Tarasiewicz, działaczka podziemia, w późniejszych latach zaangażowana w ruch kobiecy, zastanawia się nad źródłem owej nieważności i dochodzi do wniosku, że kluczem było zaniechanie samych kobiet, ich obawa, że wprowadzając ten temat do debaty, ośmieszą się i unieważnią własny polityczny wysiłek:

Przez te wszystkie lata zastanawiałam się, dlaczego kobiety nie były bardziej widoczne zarówno w żądaniach, jak i władzy politycznej czy przywództwie strajków pod koniec lat 8o. Istnieje wiele teorii, które to tłumaczą, ale moim zdaniem wciąż mamy wiele niewiadomych. [...] Myślę, że sprawy kobiet do tej pory wydają się czymś gorszym, nieważnym - do tego stopnia, że same kobiety w ogóle nie chcą być z nimi utożsamiane. Bo, jak wiadomo, prawdziwy działacz zajmuje się wielką polityką, natomiast sprawy społeczne, sprawy związane z dziećmi, tym wszystkim, co jest tradycyjnie przypisywane kobietom, to nie jest wielka polityka. Kobiety chciały być tak poważne jak ci „wielcy” mężczyźni, jak Kuroń, Michnik, Geremek, i miały poczucie, że gdyby wyszły ze swoimi kobiecymi postulatami, z prawami kobiet, ich rola by się dewaluowała. ${ }^{17}$

Wszelkie próby zwrócenia uwagi na ów „nieważny temat” długo budziła zdziwienie, rozbawienie i niesmak. Lęk przed ośmieszeniem sprawiał, że kobiety nie tylko rzadko utożsamiały się z feminizmem, ale w ogóle nie chciały rozpatrywać swoich doświadczeń w kategoriach związanych z płcią. Mechanizm ten zna każdy, kto śledził spory o kobiety Solidarności towarzyszące wydaniu eseju, a potem książki Shany Penn. Autorka przeprowadziła na początku lat 9o. szereg wywiadów z działaczkami opozycji demokratycznej, m.in. z Anną Bikont, Teresą Bogucką, Anną Dodziuk, Anką Grupińską, Ewą

17 M. Tarasiewicz "Co wy tu, drogie koleżanki, tak się dajecie?”. Rozmowa M. Klaman, "Krytyka Polityczna" 8 marca 2014; https://krytykapolityczna.pl/kraj/tarasiewicz-co-wy-tu-drogiekolezanki-tak-sie-dajecie/ 
Kulik, Heleną Łuczywo, Joanną Szczęsną, Małgorzatą Tarasiewicz i Anną Walentynowicz ${ }^{18}$. Z wyjątkiem Labudy, żadna z nich nie uważała kwestii kobiecej za istotną, wszystkie w rozmowach z Penn wyrażały zdziwienie, że można serio analizować historię podziemia pod kątem relacji płci. Penn przeprowadziła swoje badania na miejscu, w Polsce. Jednak gdy pytanie o płeć w Solidarności zadawano działaczkom podziemia przebywającym poza krajem, groźba unieważnienia przestawała działać, polityczny wymiar płci stawał się oczywisty. Słyszałam wiele opowieści o genderowej rewizji prywatnej pamięci podczas pobytu za granicą, doświadczenie to było także moim udziałem - piszę o tym we wstępie do Świata bez kobiet. Tu jednak przytoczę opowieść Katarzyny Zimmerer:

[...] w 1982, jeździłam z wykładami na temat „Solidarności”, NZS-u, zadawano mi pytania o ruch feministyczny w Polsce - to ja patrzyłam na pytających jak na debili. Przecież tutaj nie chodziło o wyzwolenie kobiet, tylko o prawdziwą walkę ze złem przez duże Z. A my, Polki, jesteśmy wyzwolone, bo my już od powstań... Ale jak przyjechałam do Polski [w 1987] i się nagle okazywało, że moi koledzy mówią do moich koleżanek „to zrób mi, cipciu, herbaty”, i moje koleżanki bez słowa wstają od stołu, robią herbatę... Albo że ci faceci w ogóle nie zmywają, nie piora - to mnie to szokowało. Ale nikt nie widział w tym niczego szczególnego. Bo przecież mój ciaptuś w kuchni to by się pogubił, ciaptuś ma dwie lewe ręce, ja ciaptusiowi usmażę jajeczniczkę. I to było przerażające dla mnie, ja się z dużym trudem dogadywałam wtedy ze znajomymi na poziomie najbardziej codziennym. Już potem trudno mi było do końca poważnie traktować te różne ciaptusie, jak opowiadały o ruchu Wolność i Pokój. ${ }^{19}$

Zimmerer filtruje wspomnienia z Polski lat 8o. przez nabytą w Niemczech feministyczną wrażliwość, dzięki czemu jej relacja trafnie oddaje groteskowy wymiar ówczesnej obyczajowości. Pamiętam to połączenie

18 Owocem tych badań był najpierw artykuł pt. Tajemnica państwowa opublikowany w feministycznym piśmie "Pełnym Głosem” (1994 nr 2) i przywołany przeze mnie w tekście Patriarchat poSeksmisji ("Gazeta Wyborcza” 19-20 czerwca 1999), a potem książki S. Penn Podziemie kobiet, Rosner i Wspólnicy, Warszawa 2003, oraz Sekret Solidarności, W.A.B., Warszawa 2014.

19 Wspomnienia z tomu: A. Grupińska, J. Wawrzyniak Buntownicy. Polskie lata 70. i 80., Świat Książki, Warszawa 2011, s. 449. Dziękuję Agnieszce Grzybek na zwrócenie uwagi na tę opowieść. 
czułości i lekceważenia w relacjach męsko-damskich. Pamiętam łatwość, z jaką kobiety racjonalizowały własną marginalizację i nieustanną pracę na zapleczu jako konieczną dla sprawy obsługę mężczyzny postrzeganego jako „ciaptuś”. Z tej właśnie obyczajowości - a nie ze statusu kobiet jako równych mężczyznom "osób” - wyrasta uniwersalizacja podmiotu politycznego widoczna w tekście Lipskiego. Uniwersalizacja ta jest raczej ucieczką od problemu nierówności niż jego rozwiązaniem. Czy to ważne, kto zmywa i kto robi herbatę oraz kto kogo z czułością nazywa "ciaptusiem" i smaży mu „jajeczniczkę", skoro wszyscy razem - kobiety i mężczyźni - walczyli z komuną? Otóż staje się ważne, gdy zgodzimy się dostrzec polityczny wymiar prywatności. I nie chodzi tu tylko o jajeczniczkę dla ciaptusia, chodzi także o prawo kobiet do samostanowienia. Nikt nie miał wątpliwości, jakie będą żądania Kościoła w tej sferze, a jednak nikt o tym wtedy nie mówił. Temat pojawił się dopiero na początku lat 9o., a i wtedy często był zbywany jako „zastępczy”.

$* * *$

Co naprawdę sądził Jan Józef Lipski o roli Kościoła i o kulcie Jana Pawła II w ówczesnej Polsce, wiemy z innych jego esejów - tych, które zgodnie z logiką gatunku stanowią „próby” kompleksowego zmierzenia się z tym tematem i z własną wobec niego ambiwalencją. Jak jednak wspomniałam na początku, Dwie ojczyzny nie są w tym znaczeniu esejem. To starannie skonstruowany polityczny manifest, tekst performatywny, którego zadaniem było raczej ustanowienie pewnego porządku niż jego analiza. Chodziło o stworzenie ideowej niszy dla lewicowego nurtu opozycji, dla środowiska KOR-u osaczonego z dwóch stron przez nacjonalistów. Tekst Lipskiego powstał po to, by nie oddać polskości narodowcom, by uchronić Solidarność przed dyktatem „prawdziwych Polaków”. Lipski przywołuje tradycję piłsudczykowską: deklaruje miłość wobec ojczyzny, walczy o niepodległość, jednocześnie dystansując się od megalomanii narodowej. Jednak w 1981 warunkiem utrzymania tej konstrukcji w pionie jest podparcie jej autorytetem Kościoła. Dlatego Lipski pisze o liście biskupów z 1965 roku, ale nie wspomina o politycznych ambicjach Wyszyńskiego. Wspomina o antysemickich nastrojach podsycanych przez Kościół przed wojną, ale kilkakrotnie przywołuje Rosję - nie zaś polski katolicyzm - jako źródło antysemickich obsesji polskich nacjonalistów. Pisze o szmalcownikach, ale natychmiast przywołuje sprawiedliwych. I chętniej niż o katolicyzmie wspomina o chrześcijaństwie. 
Od pominięć i uniwersalizacji, które starałam się tu zarysować, zależało być albo nie być formacji kulturowej, której młodzieżówkę stanowiło nasze kółko samokształceniowe, a która kilka lat wcześniej wydała z siebie inny manifest: Kościót, lewica, dialog Adama Michnika. Nie ulega wątpliwości, że jego autor dał się Kościołowi uwieść, a niedawny głośny wywiad, w którym broni Kościoła i wiary przed obecną „destrukcyjną krytyką”, jest dowodem trwałości tego uwiedzenia ${ }^{20}$. Lipski był człowiekiem niewierzącym, co wielokrotnie publicznie deklarował. Był też - pisze o tym w eseju O roli Kościoła w Polsce z 1990 roku - zwolennikiem ostrego rozdziału państwa i kościoła. Jednak jako autor Dwóch ojczyzn wypowiadał się przede wszystkim z pozycji czołowego przedstawiciela opozycyjnej „lewicy laickiej” - środowiska, dla którego walka z komuną w oczywisty sposób implikowała sojusz z Kościołem katolickim. Uważa się dziś powszechnie, że opozycja była na ów sojusz skazana - i zapewne tak było. Owa nieuchronność doprowadziła jednak do przeoczenia faktu, że jest to instytucja ze swej istoty niedemokratyczna. Jej interesy, rozbieżne przecież z ideą nowoczesnej demokracji, oznaczały dla opozycji wymazanie z pola widzenia kwestii kobiecej. Budowanie otwartego patriotyzmu w kraju, gdzie patriotyczny rytuał odbywa się w znacznej mierze w kościołach, musiało mieć polityczne konsekwencje. Odczuły je przede wszystkim kobiety, których istnienie projekt ten pomijał.

20 A. Michnik Wierzę w tajemnicę. Ja nie umiałbym powiedzieć, że jestem ateistą. Rozmawia D. Wielowieyska, "Gazeta Wyborcza” 2 kwietnia 2021. 


\section{Abstract}

\section{Agnieszka Graff}

UNIVERSITY OF WARSAW

"No One Saw Anything Special in It": Omissions and Generalisations in Jan Józef Lipski's Two Homelands and Their Implications

Graff reads Jan Józef Lipski's essay Dwie ojczyzny, dwa patriotyzmy [Two Homelands, Two Patriotisms] as a manifesto of the secular leftist opposition. In 1981 it was attacked by "the real Poles" within "Solidarity" and by the regime's "Grunwald" group. His project of a critical patriotism rooted in the Christian tradition counters these attacks, but the political identity constructed in it is based on certain omissions and generalisations. Lipski idealises the Catholic Church and overlooks its role in fostering nationalism. He also omits women, both as individuals and as a collective, making an alliance with the Church a risk to women. Lipski's essay - formative for the generation of the transformation - has contributed to establishing the hegemony of the Catholic Church in democratic Poland and to women's exclusion from the public debate.

\section{Keywords}

Jan Józef Lipski, secular left, nationalism, Catholic Church, women 